\title{
Morphometric Characterization of Yankasa Sheep in Bauchi South
}

\section{of Bauchi State, Nigeria}

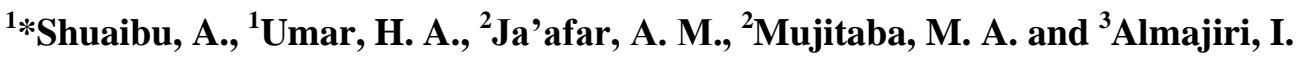 \\ ${ }^{1}$ Department of Animal Science \\ Faculty of Agriculture, Federal University of Kashere, Gombe State, Nigeria \\ ${ }^{2}$ Department of Animal Production \\ Faculty of Agriculture, Abubakar Tafawa Balewa University, Bauchi, Nigeria \\ ${ }^{3}$ College of Education Kangere P. M. B. 0316, Bauchi \\ Bauchi State, Nigeria.
}

\begin{abstract}
This study was carried out in Bauchi, Dass and Tafawa Balewa Local Government Areas of Bauchi State, between January and April 2018, to determine the characteristics of some morphometric traits in Yankasa sheep. A total of 450 sheep (200 males and 250 females) with varied age groups (>1 year = 0PPI, $<1$ year $=1$ PPI, 2 years $=2 \mathrm{PPI},<2-3$ years $=3 \mathrm{PPI}$ and $3.5-4$ years and above $=4 \mathrm{PPI})$ were used. The traits measured include; Live weight (LW), face length (FL), horn length (HL), ear length (EL), neck length (NL), girth circumference (GC), body length (BL), wither height (WH), leg length (LL), Loin girth (LG), rump width (RW), canon circumference (CC), tail length (TL), testicular circumference (TC), testicular length (TCL), teat length (TTL) and udder circumference (UC). Data generated were subjected to descriptive statistics and multivariate analysis of variance and Pearson correlation analysis between traits were estimated. The coefficient of variation of the variables ranged from $6.43 \%$ for testicular length to $27.33 \%$ for teat length. The mean LW, FL, HL, EL, NL, GC, BL, WH, LL, LG, RW, CC, TL, TC, TCL, TTL and UC were $27.66 \mathrm{~kg}, 13.02 \mathrm{~cm}, 15.54 \mathrm{~cm}, 14.39 \mathrm{~cm}, 28.73 \mathrm{~cm}, 68.45 \mathrm{~cm}, 56.45 \mathrm{~cm}, 53.97 \mathrm{~cm}, 36.94 \mathrm{~cm}, 70.48 \mathrm{~cm}, 15.44 \mathrm{~cm}$, $8.45 \mathrm{~cm}, 41.68 \mathrm{~cm}, 24.11 \mathrm{~cm}, 15.56 \mathrm{~cm}, 1.61 \mathrm{~cm}$ and $22.67 \mathrm{~cm}$, respectively. The result revealed that Location had an effect on most of the parameters observed. Sheep found in Bauchi had higher values for all the significantly affected traits. Except for wither height and ear length, males were significantly higher than females in all the body traits recorded. Age wise, sheep with 4PPI (four pairs of permanent incisors) had the highest for all the parameters measured. The correlation coefficients among the traits in both sexes were mostly moderate to high and significant $(\mathrm{P}<0.01)$. Thus, if values of some of the parameters are known they could give the indication of the values of others. Conclusively, the location should be considered when designing a breeding program of Yankasa sheep in this area.
\end{abstract}

Keywords: Morphometric, Characterization, Yankasa, Correlation.

\subsection{INTRODUCTION}

Domestic animals have been part of the living world since the beginning of human history [12]. Over the years, they have developed unique combinations of traits through adaptation to best respond to specific pressures presented by different ecological and cultural environments [20]. This has brought about a great genetic diversity which has given birth to many different breeds of domestic animals. These breeds contribute greatly to the world's genetic diversity, and are particularly well adapted to specific local conditions where exotic breeds would not survive. Unfortunately, the natural variability, procured over thousands of years, is becoming increasingly endangered [28, 15, 22, 13, 21]. [28] highlighted that high human population growth rate and the desire for higher living standards, combined, are pressuring local livestock keepers to increase production. Hence the need to concentrate on specialized, narrow ranged genotypes, suitable for current production and market conditions [28, 13]. The FAO's Global Databank for Animal Genetic Resources has information on a total of 7616 livestock breeds [13], of which $20.0 \%$ are classified as at risk. Already, $14.0 \%$ of sheep breeds globally are extinct [13]. Sixty-two breeds have become extinct during the last six yearsthe loss amounting to almost one breed per month and these figures give a partial picture of genetic erosion. Breed inventories, and particularly surveys of population size and structure at breed level, are not complete in many parts of the world. Population data are unavailable for $36.0 \%$ of all breeds [13]. Unrecorded genetic resources are being lost before their characteristics can be studied and their potential evaluated $[28,13]$. This lack of data is a serious constraint to effective prioritization and planning of 
breed conservation measures [13]. [29] indicated that studies are necessary to characterize, identify and differentiate breed populations. [9] have put emphasis on identifying the origin and history of breeds, as well as their geographical distribution, qualities and aptitudes, phenotypic description and morphological traits. The need to characterize livestock breeds has led to the formulation of 'The Global Plan of Action for Animal Genetic Resources' by FAO which recognizes that "a good understanding of breed characteristics is necessary to guide decision-making in livestock development and breeding programs" at local, national, regional and global levels [13]. Research, training programs and monitoring of trends in distribution and loss of biodiversity in the regions covered will also make use of the compiled database [28]. Once their potential is known, the indigenous breeds can be better utilized as part of sustainable farming systems [22].

\subsection{MATERIALS AND METHODS}

\subsection{Location and climate}

The study was conducted at Bauchi, Dass and Tafawa Balewa Local Government Areas of Bauchi State from February to May, 2018. Bauchi state is located between Latitude $9^{\circ} 3^{\prime}$ and $12^{\circ} 3^{\prime}$ North and Longitude $8^{\circ} 50^{\prime}$ and $11^{\circ}$ East [2]. The rainfall in Bauchi state ranges between $1300 \mathrm{~mm}$ per annum in the south and only $700 \mathrm{~mm}$ in the extreme north [26]. The average relative humidity and temperature values range between 35-94 \% for months of February and August and 36.6-12.8 $\mathrm{C}$ during April and December, respectively. It spans three vegetation zones, namely, northern guinea, Sudan and Sahel savannahs [2].

Table 1: Locations and annual rain fall of the selected local government areas

\begin{tabular}{lllll}
\hline Local Government & Longitude & Latitude & Elevation & Annual rain fall \\
\hline Bauchi & $09.85^{\circ} \mathrm{E}$ & $10.31^{\circ} \mathrm{N}$ & $628 \mathrm{~m}$ & $1009 \mathrm{~mm}$ \\
Dass & $10.00^{\circ} \mathrm{E}$ & $09.52^{\circ} \mathrm{N}$ & $700 \mathrm{~m}$ & $>1000 \mathrm{~mm}$ \\
Tafawa Balewa & $10.31^{\circ} \mathrm{E}$ & $09.84^{\circ} \mathrm{N}$ & $630 \mathrm{~m}$ & $1000-1200 \mathrm{~mm}$ \\
\hline
\end{tabular}

[2] Abubakar, 1974

\subsection{Animal Management and Data Collection}

A total number of 450 Yankasa sheep comprising of both sexes (200 males and 250 females) at different ages $(>1$ year $=0$ PPI, < 1 year $=1$ PPI, 2 years $=2$ PPI, $<2-3$ years $=3$ PPI and 3.5-4 years above $=4$ PPI) were sampled from traditionally managed flocks and some selected local markets (Mararraba, Liman Katagun and Gwallaga) in Bauchi, Dass and Tafawa Balewa Local Government Areas of Bauchi State. Animals were managed either extensively or semi-intensively. Live weight was measured along with sixteen linear body measurements on each animal. They were face length (FL), horn length (HL), ear length (EL), neck length (NL), girth circumference (GC), body length (BL), wither height (WH), leg length (LL). Loin girth (LG), rump width $(\mathrm{RW})$, canon circumference (CC), tail length (TL), testicular circumference (TC), testicular length (TCL), teat length (TTL) and udder circumference (UC). A graduated measuring stick was used for the height measurements, while the length and circumference were done using a tailors' tape; and a calipers was used for the width measurements.

\subsection{Data Analysis}

Data generated were subjected to descriptive statistics (mean, standard deviation and coefficient of variation) and analysis of variance (ANOVA) using the general linear model (GLM) procedure of SPSS, version 22 (2013). Significantly different means were compared using the least significant differences (LSD). The model utilized was as follow:

$\mathrm{Y}_{\mathrm{ijk}}=\mathbf{U}+\mathbf{L}_{\mathrm{i}}+\mathbf{S}_{\mathrm{j}}+\mathrm{A}_{\mathrm{k}}+\mathbf{e}_{\mathrm{ijk}}$

$\mathbf{Y}_{\mathrm{ijk}}=$ Observation on dependent variables

$\mathbf{U}=$ Common Mean

$\mathbf{L}_{\mathrm{i}}=$ effect of $\mathrm{i}^{\text {th }}$ location $(1,2,3)$

$\mathbf{S}_{\mathrm{j}=}$ effect of $\mathrm{j}^{\text {th }} \operatorname{sex}(1,2)$

$\mathbf{A}_{\mathrm{k}=}$ effect of $\mathrm{k}^{\text {th }}$ age $(1,2,3,4,5)$

$\mathbf{e}_{\mathrm{ijk}}=$ random error term

The relationships between live weight and linear body measurements were determined using the Pearson's product moment correlation.

\subsection{RESULTS}

The means, standard deviations and coefficients of variability of live weight and linear body measurements observed in Yankasa Sheep are presented in Table 2. The coefficient of variation (CV) ranged from $6.43 \%$ for testicular length to $27.33 \%$ for teat length. The average morphometric traits (live weight and linear measurements) according to location, sex and age are presented in Tables 3, 4 and 5, respectively. Significant effect of location on ear, neck, body and leg lengths, girth and testicular circumferences and rump width $(\mathrm{P}<0.05)$, live weight, wither height, tail length and udder circumference $(\mathrm{P}<0.001)$ was observed. Bauchi Local Government had the heaviest sheep with longer ear and tail and wider girth, udder and testicle while in Dass, lighter sheep with shorter ear and tails and narrower girth, udder and testicle were observed $(28.51 \pm 0.51 \mathrm{~kg}, 15.03 \pm 0.13 \mathrm{~cm}, 44.77 \pm 0.45$ 
$\mathrm{cm}, 71.23 \pm 0.90 \mathrm{~cm}, 28.80 \pm 0.64 \mathrm{~cm}$ and $25.41 \pm 0.43 \mathrm{~cm}$ vs $26.59 \pm 0.68 \mathrm{~kg}, 13.53 \pm 0.41 \mathrm{~cm}, 36.50 \pm 0.58 \mathrm{~cm}, 66.63 \pm 0.41 \mathrm{~cm}$, $18.95 \pm 0.53 \mathrm{~cm}$ and $22.78 \pm 0.35 \mathrm{~cm})$. Similarly, sheep with longer neck $(30.46 \pm 0.36 \mathrm{~cm})$, body $(59.00 \pm 0.55 \mathrm{~cm})$ and leg $(38.54 \pm 0.32 \mathrm{~cm})$ and higher wither $(54.10 \pm 0.51 \mathrm{~cm})$ and wider rump $(16.27 \pm 0.44 \mathrm{~cm})$ were also observed in this area. However, non-significant effect of location on face, horn, testicular and teat lengths, loin girth and canon circumference was observed. Significant effect of sex on neck length and rump width $(\mathrm{P}<0.05)$, live weight, face and neck lengths and girth circumference $(\mathrm{P}<0.01)$, body and tail lengths, loin girth and cannon circumference $(\mathrm{P}<0.001)$ was observed. Males had the heaviest weight with longer neck, face, leg, body and tail and wider rump, chest, loin and canon than females $(28.20 \pm 0.14 \mathrm{~kg}, 29.41 \pm 0.18 \mathrm{~cm}$, $13.18 \pm 0.45 \mathrm{~cm}, 37.41 \pm 0.31 \mathrm{~cm}, 58.56 \pm 1.04 \mathrm{~cm}, 42.29 \pm 0.80 \mathrm{~cm}, 15.91 \pm 0.26 \mathrm{~cm}, 69.27 \pm 0.21 \mathrm{~cm}, 72.07 \pm 0.57 \mathrm{~cm}$ and $10.00 \pm 0.27$ $\mathrm{cm}$ vs $27.63 \pm 0.20 \mathrm{~kg}, 28.08 \pm 0.22 \mathrm{~cm}, 12.20 \pm 0.42 \mathrm{~cm}, 36.47 \pm 0.37 \mathrm{~cm}, 52.61 \pm 0.47 \mathrm{~cm}, 40.47 \pm 0.61 \mathrm{~cm}, 14.97 \pm 0.12 \mathrm{~cm}$, $67.63 \pm 0.18 \mathrm{~cm}, 68.91 \pm 0.61 \mathrm{~cm}$ and $7.76 \pm 0.13 \mathrm{~cm})$. Non-significant effect of sex on ear length and wither height were however observed. Significant effect of age on ear, neck, body and teat lengths, rump width and testicular circumference $(\mathrm{P}<0.05)$, face, horn and leg lengths, loin and chest girths, wither height and canon circumference $(\mathrm{P}<0.01)$, live weight, tail, testicular lengths and udder circumference $(\mathrm{P}<0.001)$ was observed. Aged sheep (those with four pairs of permanent incisors) were observed to be the heaviest with longer face, horn, ear, neck, body, leg, tail, testicle, teat and wider girth, loin, rump, canon, testis, udder and higher wither while the younger ones (no pair of permanent incisors) had lower value for these traits $(37.84 \pm 0.33 \mathrm{~kg}, 15.74 \pm 0.68$ $\mathrm{cm}, 19.98 \pm 0.53 \mathrm{~cm}, 14.95 \pm 0.57 \mathrm{~cm}, 32.31 \pm 0.39 \mathrm{~cm}, 77.61 \pm 0.36 \mathrm{~cm}, 41.56 \pm 0.17 \mathrm{~cm}, 44.35 \pm 0.88 \mathrm{~cm}, 16.70 \pm 0.22 \mathrm{~cm}, 1.95 \pm 0.12$ $\mathrm{cm}, 77.61 \pm 0.36 \mathrm{~cm}, 78.22 \pm 0.49 \mathrm{~cm}, 17.92 \pm 0.20 \mathrm{~cm}, 11.01 \pm 0.17 \mathrm{~cm}, 23.85 \pm 0.68 \mathrm{~cm}, 24.50 \pm 0.46 \mathrm{~cm}$ and $61.10 \pm 0.24 \mathrm{~cm}$ vs $14.67 \pm 0.35 \mathrm{~kg}, 10.30 \pm 0.98 \mathrm{~cm}, 7.50 \pm 0.00 \mathrm{~cm}, 13.76 \pm 0.67 \mathrm{~cm}, 22.82 \pm 0.23 \mathrm{~cm}, 49.70 \pm 0.92 \mathrm{~cm}, 30.75 \pm 0.29 \mathrm{~cm}, 39.36 \pm 0.48 \mathrm{~cm}$, $14.00 \pm 0.09 \mathrm{~cm}, 0.99 \pm 0.24 \mathrm{~cm}, 60.26 \pm 0.50 \mathrm{~cm}, 64.50 \pm 0.58 \mathrm{~cm}, 12.88 \pm 0.22 \mathrm{~cm}, 7.63 \pm 0.73 \mathrm{~cm}, 21.00 \pm 0.40 \mathrm{~cm}, 17.30 \pm 0.50 \mathrm{~cm}$ and $45.72 \pm 0.63 \mathrm{~cm}$ ). The correlation coefficients among the morphometric traits (live weight and linear body measurements) in both sexes were as shown in table 6 and 7. Phenotypic correlations among the body measurements were in general low to moderate, positive and significant except between girth circumference and body length, wither height and body length, loin girth and chest girth in which higher values were recorded in both males in females $(0.831,0.754$ and 0.746 while the corresponding values for females were $0.772,0.751$ and 0.846 ). Correlation coefficient between the live weight and linear body measurements ranged from 0.217 to 0.980 for males and 0.114 to 0.926 for females. Girth circumference was found to have the highest coefficient $\left(r_{=}=.980\right.$ and 0.926 for male and female sheep, respectively)

\subsection{DISCUSSION}

The coefficients of variation $(\mathrm{CV})$ of morphometric traits (live weight and linear body measurements) observed in the present study among Yankasa sheep varied widely, indicating that the genetic resources of this breed is untapped. [1] reported CV of $12.89,5.36,5.51,4.76,20.88,16.56$ and $14.82 \%$ for live weight, chest girth, body length, wither height, rump width, ear length, tail length and scrotal circumference, respectively among indigenous sheep type native to Ethiopia. Similarly, [5] recorded respective values of $17.10,6.51,5.74,6.09,22.34,9.61$ and $8.60 \%$ for live weight, body length, wither height, chest girth, horn length, ear length and scrotal circumference in Ethiopian highland goats. More recently, [36] reported CV of $11.20 \%$ (live weight), $2.70 \%$ (body length), $3.20 \%$ (height wither), $6.60 \%$ (chest girth), $23.2 \%$ (ear length), $29.3 \%$ (tail length) and 9.2\% (scrotal circumference) in central zone of Tigray, Northern Ethiopia. The mean live weight observed in the present study is similar to the values of 27.60 and $26.00 \mathrm{~kg}$ as recorded by [10] and [7], respectively, but higher than 22.02 $\mathrm{kg}$ [3]. However, [19] and [11] detected higher body weight of 37.47 and $47.40 \mathrm{~kg}$ among Algerian and Iranian native breeds. Furthermore, [14] and [34] reported lower means of 20.60 and $18.78 \mathrm{~kg}$, respectively in Tigray region. The mean body measurements observed in this study are slightly similar to those reported by [10] in $2017(10.30 \pm 0.07,68.50 \pm 0.60,60.20 \pm 0.30,60.20 \pm 0.50,17.20 \pm 0.54$ and $24.90 \pm 1.06$ $\mathrm{cm}$ for EL, CG, BL, WH, RW and TC, respectively), [7] in 2007 (11.10 $\pm 1.08,71.40 \pm 4.70,58.75 \pm 3.28,62.10 \pm 3.80$ and $16.32 \pm 2.82 \mathrm{~cm}$ for EL, GC, BL, WH and RW, respectively), [14] in $2008(65.10 \pm 0.22,53.50 \pm 0.17,58.40 \pm 0.16$ and $18.10 \pm 0.07$ $\mathrm{cm}$ for GC, BL, WH and RW, respectively) and [1] in 2014 with respective values of 75.34 $\pm 0.20,62.59 \pm 0.20,65.43 \pm 0.10$, $16.70 \pm 0.10,9.49 \pm 0.10$ and $21.90 \pm 0.26 \mathrm{~cm}$ for GC, BL, WH, RW, EL and SC. The fact that location had considerable effect on morphometric measurements (live weight and linear body measurements) is well documented [25]. The higher means observed in Bauchi compared to Dass and Tafawa Balewa on most morphometric traits investigated showed that the genetic constitution of this breed in different location varied. The report of [32] also indicated that genetic constitution of sub-population and availability of natural pastoral land could cause a marked variation on biometric measurements of indigenous Yankasa breed of sheep. Similar assertion was also made by [24] and [36]. Working on local chickens, [6] reported significant effect of location on live and egg weights and body length in Adamawa state of Nigeria. Sexual dimorphisms of morphometric traits observed in this study is in agreement with the finding of [33]. The authors observed that males were superior to females in all the morphometric traits investigated and attributed this differences to genes linked with sex chromosomes. They further suggested that males possess genes for faster growth and larger body size and are located on the Y-chromosomes. Similarly, several investigators [37, 39, 17] recorded higher live weight means in males than females and opined this condition to hormonal difference between the two sexes. These observations also conform with the reports of [4] among Ethiopian sheep types. The authors recorded higher values for males than females in all the parameters measured and noticed that sexual dimorphism in sheep is manifested with respect to a 
large number of body attributes and in most breeds. Similar report by [36] in Tanqua-Abergelle, Kola-Tembien and Adwa districts of Ethiopia also detected considerable effect of sex on body measurements. The authors attributed this to differential effects of androgens and estrogens and suggested that the latter produced in females restrict the growth and development of long bones. Furthermore, many researchers $[37,31,35]$ reported lower values for female than male sheep. According to the authors, this may be due to sex hormones which promote larger muscle development in the latter. The significant effect of age on morphometric traits observed in the current study agrees with the work of many [37, 3, 23]. They noticed that adult sheep were heavier than the younger ones and higher in all linear body measurements. Similarly, [17], [24] and [36] recorded higher values for all morphometric traits in adult sheep as compared to the younger ones at different ages. The authors further explained that selective improvement of these traits should be emphasized at this stage (adult). The positive correlations observed among most of the morphometric measurements show that the traits can be used to indicate each other i.e. if one has high value so also will likely be the other. The moderate to high correlation between the morphometric traits observed in males agree with the findings of [38]. In particular, the strong and positive correlations observed between girth circumference and body length, body length and wither height and loin girth and girth circumference in both sexes is in-line with the work of [30]. Similar to the current finding, [27] reported higher correlation coefficients among heart girth, body length and wither height in Saneen goats. The higher coefficients observed between most of the body measurements and live weight showed that the latter can be predicted from the former with good accuracy. It is on this basis weighing bans were designed. Reports from several authors indicated that strong relationship existed between live weight and body measurements and attributed this fact to pleiotropic gene action $[18,8,16]$.

\subsection{CONCLUSIONS}

I. The coefficients of variation recorded among the morphometric measurements (live weight and linear body measurements) were moderate to high.

I. Location, sex and age had significant effect on all the morphometric traits observed.

II. The relationship among the studied traits were mostly moderate to high which shows that they can indicate each other.

\subsection{CONFLICT OF INTEREST}

With regards to this research, the authors declare that they have no conflicting interest

\subsection{ACKNOWLEGMENT}

We express our profound gratitude to some local farmers in the study area for giving us access to their animals and also to some livestock dealers in Bauchi, Dass and Tafawa Balewa main livestock markets.

\subsection{REFERENCES}

1. Abera, B., Kebede, K., Gizaw, S. and Feyera, T. (2014). On-farm phenotypic characterization of indigenous sheep types in Selale Area, Central Ethiopia. Journal of Veterinary Science and Technology, 6: 31-35.

2. Abubakar, Y. A. (1974). The establishment and development of Emirate Government Bauchi, 1805-1903. Unpublished Ph.D. Dissertation, Department of History, Ahmadu Bello University, Zaria, Nigeria.

3. Afolayan, R. A., Adeyinka, I. A. and Lakpini, C. A. M. (2006). The estimation of live weight from body measurements in Yankasa sheep. Czech Journal of Animal Science, 51(8): 343-348.

4. Aklilu, E., Kebede, K., Dessie, T. and Banerjee, A. K. (2013). Phenotypic characterization of Indigenous indigenous sheep in Ethiopia. International Journal of Interdisciplinary and Multidisciplinary studies, 1(1): 24-32.

5. Alemu, A. (2015). On-Farm phenotypic characterization and performance evaluation of Abergelle and central high land goat breeds as an input for designing community based breeding program. M. Sc. Thesis, University of Haramaya University.

6. Apuno, A. A., Mbap, S. T. and Ibrahim, T. (2011). Characterisation of local chickens in Shelleng and Song Local Government Area of Adamawa State, Nigeria. Agriculture and Biology Journal of North America, 2(1): 6-14.

7. Asefa, B., Abata, T. and Adugna, E. (2017). Phenotypic characterization of indigenous sheep types in Bale zone, Oromia Regional State, Ethiopia. Journal of Veterinary Science and Technology, 8:45-52.

8. Birteeb, P. T. and Ozoje, M. O. (2012). Prediction of live body weight from linear body measurement of West African long legged and West African dwarf sheep in Northern Ghana. Online Journal of animal and Feed Research, 2: $425-434$. 
9. Carneiro, M., Blanco-Aguiar, J. A., Villafuerte, R., Ferrand, N. and Nachman, M. W. (2010). Speciation in the European Rabbit (Oryctolagus Cuniculus): Islands of differentiation on the X chromosome and autosomes. Evolution, 64: 34433460.

10. Dando, H. K. (2017). On-Farm phenotypic characterization and consumer preference traits of indigenous sheep type as an input for designing community based breeding program in Bensa district, Southern Ethiopia. M. Sc. Thesis, University of Haramaya, Haramaya.

11. Dekhili, M. (2014). A morphometric study of sheep reared in North-East Algeria. Archivos de zootecnia,63(244): 623631.

12. Epstein, H. (1971). The Origin of the Domesticated Animals of Africa. Africana Publ. Corp., New York, London, Munich, 1:1-573.

13. Food and Agriculture Organisation (FAO), (2009). The state of food and agriculture: livestock in balance. Rome: Electronic Publishing Policy and Support Branch Communication Division, FAO Rome, Italy.

14. Getachew, T. M. (2008). Characterization of Menz and Afar indigenous sheep breeds of small holders and pastoralist for designing community-based breeding strategies in Ethiopia. M. Sc. Thesis, Haramaya University, Haramaya.

15. Hall S. J. G. (2004). Livestock Biodiversity. Genetic Resources for the Farming of the Future. Blackwell Publishing, Oxford

16. Iqbal, Z. M., Javed, K., Abdullahi, M., Ahmad, N., Ali, A., Khalique, A., Aslam, N. and Younas, S. (2014) Estimation of body weighth from different morphometric measurements in Kajli lambs. The Journal of Animal and plant sciences, 24(3): 700-703.

17. Iyiola-Tunji, A. O., Akpa, G. N. and Nwagu, B. I. (2015). Prediction of body weight of sheep of Northern Nigeria using linear body measurements Proceedings Ghana Society of Animal Production Conference. Pp.29-38.

18. Khan, H., Muhammad, F., Ahmad, R., Nawaz, G., Rahimullah and Zubair, M. (2006). Relationship of body weight with linear body measurements in goats. Journal of Agriculture and Biological Science, 1(3): 51-54.

19. Kiyanzard, M. R. (2004). Using linear body measurements at live sheep to predict carcass characteristics for two Iranian fat-tailed sheep breeds. Asian-Australian Journal of Animal Sciences, 17(5): 693-699.

20. Köhler-Rollefson, I. (2000). Management of animal genetic diversity at community level. A report prepared for GTZ

21. Kosgey, I. S., Rowlands, G. J., Van Arendonk, J. A. M. and Baker, R. L. (2008). Small ruminant production in small holder and pastoral/extensive farming systems in Kenya. Small Ruminants Research, 77: 11-24.

22. Kunene, N. W. and Fossey, A. (2006). A survey on livestock production in some traditional areas of Northern Kwazulu Natal in South Africa. Livestock Research for Rural Development. Volume 18, Article \#113. Retrieved February 3, 2019, fromhttp://www.lrrd.org/lrrd18/8/kune18113.htm

23. Mavule, B., Muchenje, V., Bezuidenhout, C. and Kunene, N. (2013). Morphological structure of Zulu sheep based on principal component analysis of body measurements. Small Ruminant Research, 111(1):23-30.

24. Mekuriawa, S., Mekuriawb, Z., Tayeb, M., Mekuriawb, G., Amanea, A., T. Bimrewa, T. and Haile, A. (2013). Growth performance and linear body measurements of Washera, Farta and their crossbreed sheep under farmers' management system in Western Highland of Amhara Region. Scientific Journal of Veterinary Advances, 2(9): 132-143.

25. Melesse. A., Banerjee, S., Lakew, A., Mersha, F., Hailemariam, F., Tsegaye, S. and Makebo, T. (2013). Morphological characterization of indigenous sheep in Southern Regional State, Ethiopia. Animal Genetic Resources, 10: 5239-5250.

26. Muhammad, B. Y. (2003). Bauchi State Economic, Political and Social Survey.1st Edition, The Open Press Ltd, Zaria, Kaduna State, Nigeria. Pp.6-8

27. Pesmen, G and Yardimci, M. (2008). Estimating the live weight using some body measurements in Saanen goats. Archiva Zootechnica, 11(4): 30-40.

28. Rege, J. E. O. and Lipner, M. E. (1992). African Animal Genetic Resource: Their Characterization, Conservation and Utilization. Proceedings of the Research Planning Workshop held at ILCA, Addis Ababa, Ethiopia 19-21 February 1992. 
International Journal of Advances in Scientific Research and Engineering (ijasre), Vol 5 (2), February-2019

29. Rodero, E. Y. and Herrera, M. (2000). El concepto de raza. Un enfoque epistemológico. Arch. Zootec. 49: 5-16.

30. Salako, A. E. (2006). Application of Morphological indices in the assessment of type and function in sheep. International Journal of Morphology, 24(1): 13-18.

31. Semakula, J., Mutetikka, D., Kugonza, R. D. and Mpairwe, D. (2010). Variability in body morphometric measurements and their application in predicting live body weight of Mubende and Small East African Goat breeds in Uganda. MiddleEast Journal of Scientific Research, 5(2): 98-105.

32. Shuaibu, A., Aliyu, A., Ja'afar, A. M., Ma'aruf, B. S. and Mujitaba, M. A. (2018). Phenotypic Characterization of Yankasa Sheep in Northern Agricultural Zone of Bauchi State, Nigeria. Nigerian Journal of Animal Science and Technology, 1 (2):36-45.

33. Sownade, O. S. and Sobola, O. S. (2008). Body measurements of West African Dwarf sheep as parameters for estimation of live weight. Tropical Animal Health and Production, 40: 433-439.

34. Tadesse, A. and Gebremariam, T. (2010). Application of linear body measurements for live body weight estimation of high sheep in Tigray region, North-Ethipia. Journal of the Dry land, 3(2): 203-207.

35. Taye, M., Bimerow, T., Yitayew, A., Mekuriaw, S. and Mekuriaw, G. (2011). Estimation of live body weight from linear body measurements for Farta sheep. Online Journal of Animal and Feed Research, 2(1): 98-103.

36. Tesfay, H. H., Banrejee, A. K and Mummed, Y. Y. (2017). Live body weight and linear measurements of indigenous sheep population in their production system for developing suitable selection criteria in central zone of Tigray, Northern Ethiopia. African Journal of Agricultural Research, 12(13): 1087-1095.

37. Thiruvenkadan, A. K. (2005). Determination of best-fitted regression model for estimation of body weight in Kanni Adu kids under farmer's management system. Livestock Research for Rural Development, 17 (7) 2005.

38. Tsegaye, D., Belay, B. and Haila, A. (2013). Linear body measurements as a predictor of body weight Hararaghe high land goats, under farmers' environment: Ethiopia. Global Veterinaria, 11(15): 649-656.

39. Zewdu, E. (2008). Characterization of Bonga and Horro indigenous sheep breeds of small holders for designing community-based breeding strategies in Ethiopia. An MSc Thesis Presented to the School of Graduate Studies of Haramaya University, Haramaya.

Table 2: Descriptive statistics of live weight $(\mathrm{kg})$ and linear body measurements $(\mathrm{cm})$

\begin{tabular}{llll}
\hline Parameters & Mean & SD & CV \\
\hline BW & 27.66 & 1.92 & 6.94 \\
FL & 13.02 & 0.97 & 7.45 \\
HL & 15.54 & 2.95 & 18.19 \\
EL & 14.39 & 2.03 & 14.11 \\
NL & 28.73 & 3.46 & 12.04 \\
GC & 68.45 & 6.14 & 8.97 \\
BL & 56.45 & 8.79 & 15.57 \\
WH & 53.97 & 5.20 & 9.85 \\
LL & 36.94 & 4.98 & 13.48 \\
LG & 70.49 & 8.32 & 11.80 \\
RW & 15.44 & 2.46 & 15.93 \\
CC & 8.45 & 1.09 & 12.90 \\
TL & 41.68 & 4.47 & 10.72 \\
TC & 24.11 & 2.07 & 8.59 \\
TCL & 15.56 & 1.00 & 6.43 \\
TTL & 1.61 & 0.44 & 27.33 \\
UC & 22.67 & 5.10 & 22.50 \\
\hline
\end{tabular}

BW = Body weight, FL = Face length, HL = Horn length, EL = Ear length, NL = Neck length, GC = Girth circumference, $\mathrm{BL}=$ Body length, $\mathrm{WH}=$ Wither height, $\mathrm{LL}=\mathrm{Leg}$ length, $\mathrm{LG}=$ Loin girth, $\mathrm{RW}=$ Rump width, $\mathrm{CC}=\mathrm{Cannon}$ circumference, $\mathrm{TC}$ $=$ Testicular circumference, $\mathrm{TL}=$ Tail length, $\mathrm{TCL}=$ Testicular length, $\mathrm{TTL}=$ Teat length, UC = Udder circumference, $\mathrm{SD}=$ Standard deviation and CV $=$ Coefficient of variability. 
International Journal of Advances in Scientific Research and Engineering (ijasre), Vol 5 (2), February-2019

Table 3: Average live weight (kg) and linear body measurements $(\mathrm{cm})$ according to location

\begin{tabular}{|c|c|c|c|c|c|}
\hline Parameters & Overall mean \pm S.E & Bauchi & Dass & Tafawa Balewa & LOS \\
\hline $\mathrm{LW}$ & $27.66 \pm 0.10$ & $28.51 \pm 0.15^{\mathrm{a}}$ & $26.59 \pm 0.68^{c}$ & $27.87 \pm 0.27^{b}$ & $* * *$ \\
\hline FL & $13.02 \pm 0.05$ & $12.98 \pm 0.61$ & $13.05 \pm 0.22$ & $13.02 \pm 0.19$ & NS \\
\hline HL & $15.54 \pm 0.16$ & $15.31 \pm 0.66$ & $15.69 \pm 0.24$ & $15.57 \pm 0.44$ & NS \\
\hline EL & $14.39 \pm 0.11$ & $15.03 \pm 0.13^{\mathrm{a}}$ & $13.53 \pm 0.41^{\mathrm{c}}$ & $14.61 \pm 0.43^{\mathrm{b}}$ & $*$ \\
\hline NL & $28.73 \pm 0.18$ & $30.46 \pm 0.36^{\mathrm{a}}$ & $28.50 \pm 0.12^{\mathrm{ab}}$ & $27.23 \pm 0.09^{\mathrm{b}}$ & $*$ \\
\hline GC & $68.45 \pm 0.32$ & $71.23 \pm 0.90^{\mathrm{a}}$ & $66.63 \pm 0.41^{\mathrm{c}}$ & $67.48 \pm 0.47^{\mathrm{b}}$ & $*$ \\
\hline BL & $56.45 \pm 0.46$ & $59.00 \pm 0.55^{\mathrm{a}}$ & $58.13 \pm 0.98^{\mathrm{a}}$ & $52.19 \pm 0.62^{\mathrm{b}}$ & $*$ \\
\hline WH & $53.97 \pm 0.27$ & $54.10 \pm 0.51^{\mathrm{a}}$ & $54.02 \pm 0.05^{\mathrm{a}}$ & $53.79 \pm 0.51^{\mathrm{b}}$ & $* * *$ \\
\hline LL & $36.94 \pm 0.26$ & $38.54 \pm 0.32^{\mathrm{a}}$ & $36.30 \pm 0.24^{\mathrm{b}}$ & $35.98 \pm 0.17^{\mathrm{bc}}$ & $*$ \\
\hline LG & $70.49 \pm 0.44$ & $70.85 \pm 0.43$ & $70.37 \pm 0.49$ & $70.25 \pm 0.37$ & NS \\
\hline RW & $15.44 \pm 0.13$ & $16.27 \pm 0.44^{\mathrm{a}}$ & $15.42 \pm 0.37^{\mathrm{b}}$ & $14.63 \pm 0.16^{\mathrm{c}}$ & $*$ \\
\hline $\mathrm{CC}$ & $8.45 \pm 0.06$ & $8.88 \pm 0.11$ & $8.40 \pm 0.23$ & $8.14 \pm 0.10$ & NS \\
\hline $\mathrm{TL}$ & $41.68 \pm 0.24$ & $44.77 \pm 0.45^{\mathrm{a}}$ & $36.50 \pm 0.58^{c}$ & $43.77 \pm 0.44^{\mathrm{b}}$ & $* * *$ \\
\hline $\mathrm{TC}$ & $24.11 \pm 0.11$ & $25.41 \pm 0.43^{\mathrm{a}}$ & $22.78 \pm 0.35^{\mathrm{b}}$ & $24.15 \pm 0.59^{\mathrm{ab}}$ & * \\
\hline TCL & $15.56 \pm 0.05$ & $15.54 \pm 0.28$ & $15.50 \pm 0.30$ & $15.62 \pm 0.32$ & NS \\
\hline TTL & $1.61 \pm 0.02$ & $1.62 \pm 0.19$ & $1.65 \pm 0.07$ & $1.56 \pm 0.09$ & NS \\
\hline $\mathrm{UC}$ & $22.67 \pm 0.27$ & $28.80 \pm 0.64^{\mathrm{a}}$ & $18.95 \pm 0.53^{c}$ & $25.60 \pm 1.04^{\mathrm{b}}$ & $* * *$ \\
\hline
\end{tabular}

$\mathrm{BW}=$ Body weight, FL = Face length, HL = Horn length, EL = Ear length, NL = Neck length, GC = Girth circumference, $\mathrm{BL}=$ Body length $\mathrm{WH}=$ Wither height, $\mathrm{LL}=\mathrm{Leg}$ length, $\mathrm{LG}=$ Loin girth, $\mathrm{RW}=$ Rump width, $\mathrm{CC}=\mathrm{Cannon}$ circumference, $\mathrm{TC}=$ Testicular circumference, $\mathrm{TL}=$ Tail length, $\mathrm{TCL}=$ Testicular length, $\mathrm{TTL}=$ Teat length, $\mathrm{UC}=$ Udder circumference, $*=\mathrm{P}<0.05$, $* * *=\mathrm{P}<0.001, \mathrm{NS}=$ Non-significant and LOS $=$ Level of significance.

Table 4: Average live weight (kg) and linear body measurements (cm) according to sex

\begin{tabular}{lllll}
\hline Parameters & Overall mean $\mathbf{+ S . E}$ & Male & Female & LOS \\
\hline LW & $27.66 \pm 0.10$ & $28.20 \pm 0.14$ & $27.63 \pm 0.20$ & $* *$ \\
FL & $13.02 \pm 0.05$ & $13.18 \pm 0.45$ & $12.20 \pm 0.42$ & $* *$ \\
EL & $14.39 \pm 0.11$ & $14.52 \pm 0.30$ & $14.06 \pm 0.31$ & NS \\
NL & $28.73 \pm 0.18$ & $29.41 \pm 0.18$ & $28.08 \pm 0.22$ & $*$ \\
GC & $68.45 \pm 0.32$ & $69.27 \pm 0.21$ & $67.63 \pm 0.18$ & $* *$ \\
BL & $56.45 \pm 0.46$ & $58.56 \pm 1.04$ & $52.61 \pm 0.47$ & $* *$ \\
WH & $53.97 \pm 0.27$ & $54.08 \pm 0.47$ & $53.86 \pm 0.35$ & NS \\
LL & $36.94 \pm 0.26$ & $37.41 \pm 0.31$ & $36.47 \pm 0.37$ & $* *$ \\
LG & $70.49 \pm 0.44$ & $72.07 \pm 0.57$ & $68.91 \pm 0.61$ & $* * *$ \\
RW & $15.44 \pm 0.13$ & $15.91 \pm 0.26$ & $14.97 \pm 0.12$ & $*$ \\
CC & $8.45 \pm 0.06$ & $10.00 \pm 0.27$ & $7.76 \pm 0.13$ & $* * *$ \\
TL & $41.68 \pm 0.24$ & $42.29 \pm 0.80$ & $40.47 \pm 0.61$ & $* * *$
\end{tabular}

BW = Body weight, FL = Face length, EL = Ear length, NL = Neck length, GC = Girth circumference, BL = Body length, WH $=$ Wither height, $\mathrm{LL}=$ Leg length, $\mathrm{LG}=$ Loin girth, $\mathrm{RW}=$ Rump width, $\mathrm{CC}=$ Cannon circumference, $\mathrm{TL}=\mathrm{Tail}$ length, $* *=\mathrm{P}<0.01$, $* * *=\mathrm{P}<0.001, \mathrm{NS}=$ Non-significant, $\mathrm{S} . \mathrm{E}=$ Standard error and LOS $=$ Level of significance. 
International Journal of Advances in Scientific Research and Engineering (ijasre), Vol 5 (2), February-2019

Table 5: Average body weight $(\mathrm{kg})$ and linear body measurements $(\mathrm{cm})$ according to age

\begin{tabular}{|c|c|c|c|c|c|c|c|}
\hline Parameters & $\begin{array}{l}\text { Overall } \\
\text { mean } \pm \text { S.E }\end{array}$ & 0PPI & 1PPI & 2 PPI & 3 PPI & 4 PPI & LOS \\
\hline LW & $27.66 \pm 0.10$ & $14.67 \pm 0.35^{\mathrm{c}}$ & $25.46 \pm 0.12^{b}$ & $28.47 \pm 0.38^{b}$ & $31.86 \pm 0.95^{\mathrm{ab}}$ & $37.84 \pm 0.33^{\mathrm{a}}$ & $* * *$ \\
\hline FL & $13.02 \pm 0.05$ & $10.30 \pm 0.98^{c}$ & $11.55 \pm 0.58^{c}$ & $12.89 \pm 0.77^{b}$ & $14.57 \pm 3.80^{\mathrm{ab}}$ & $15.74 \pm 0.68^{\mathrm{a}}$ & $* *$ \\
\hline $\mathrm{HL}$ & $15.54 \pm 0.16$ & $7.50 \pm 0.00^{\mathrm{e}}$ & $14.83 \pm 0.69^{d}$ & $16.60 \pm 0.86^{c}$ & $18.80 \pm 0.87^{\mathrm{b}}$ & $19.98 \pm 0.53^{\mathrm{a}}$ & $* *$ \\
\hline EL & $14.39 \pm 0.11$ & $13.76 \pm 0.67^{\mathrm{b}}$ & $14.30 \pm 0.46^{\mathrm{a}}$ & $14.50 \pm 0.44$ & $14.43 \pm 0.45$ & $14.95 \pm 0.57$ & * \\
\hline $\mathrm{NL}$ & $28.73 \pm 0.18$ & $22.82 \pm 0.23^{\mathrm{d}}$ & $25.96 \pm 0.81^{\mathrm{c}}$ & $30.64 \pm 0.25^{\mathrm{b}}$ & $31.82 \pm 0.61^{\mathrm{ab}}$ & $32.41 \pm 0.39^{\mathrm{a}}$ & $*$ \\
\hline $\mathrm{GC}$ & $68.45 \pm 0.32$ & $60.26 \pm 0.50^{\mathrm{d}}$ & $63.60 \pm 0.80^{b c}$ & $67.43 \pm 0.90^{\mathrm{b}}$ & $73.35 \pm 0.66^{\mathrm{a}}$ & $77.61 \pm 0.36^{\mathrm{a}}$ & $* *$ \\
\hline $\mathrm{BL}$ & $56.45 \pm 0.46$ & $49.70 \pm 0.92^{d}$ & $55.14 \pm 0.31^{\mathrm{c}}$ & $58.10 \pm 0.92^{b}$ & $59.30 \pm 0.28^{\mathrm{ab}}$ & $60.01 \pm 0.56^{\mathrm{a}}$ & * \\
\hline $\mathrm{WH}$ & $53.97 \pm 0.27$ & $45.72 \pm 0.63^{b c}$ & $50.86 \pm 0.29^{b}$ & $54.44 \pm 0.37^{\mathrm{ab}}$ & $57.73 \pm 0.12^{\mathrm{a}}$ & $61.10 \pm 0.24^{\mathrm{a}}$ & $* *$ \\
\hline $\mathrm{LL}$ & $36.94 \pm 0.26$ & $30.75 \pm 0.29^{d}$ & $33.13 \pm 0.27^{\mathrm{cd}}$ & $39.00 \pm 0.24^{b c}$ & $40.26 \pm 0.22^{b}$ & $41.56 \pm 0.17^{\mathrm{a}}$ & $* *$ \\
\hline LG & $70.49 \pm 0.44$ & $64.50 \pm 0.58^{e}$ & $65.27 \pm 0.52^{\mathrm{d}}$ & $69.74 \pm 0.34^{\mathrm{c}}$ & $74.72 \pm 0.77^{\mathrm{b}}$ & $78.22 \pm 0.49^{\mathrm{a}}$ & $* *$ \\
\hline $\mathrm{RW}$ & $15.44 \pm 0.13$ & $12.88 \pm 0.22^{\mathrm{d}}$ & $14.23 \pm 0.20^{c}$ & $15.64 \pm 0.25^{b}$ & $16.55 \pm 0.19^{a b}$ & $17.92 \pm 0.20^{\mathrm{a}}$ & $*$ \\
\hline $\mathrm{CC}$ & $8.45 \pm 0.06$ & $7.63 \pm 0.73^{b c}$ & $7.71 \pm 0.55^{\mathrm{bc}}$ & $7.86 \pm 0.19^{b}$ & $8.05 \pm 0.21^{\mathrm{b}}$ & $11.01 \pm 0.17^{\mathrm{a}}$ & $* *$ \\
\hline $\mathrm{TL}$ & $41.68 \pm 0.24$ & $39.36 \pm 0.48^{c}$ & $40.38 \pm 0.29^{b c}$ & $41.71 \pm 0.45^{b c}$ & $42.58 \pm 0.89^{b}$ & $44.35 \pm 0.88^{\mathrm{a}}$ & $* * *$ \\
\hline $\mathrm{TC}$ & $24.11 \pm 0.11$ & $21.00 \pm 0.40^{\mathrm{c}}$ & $24.20 \pm 0.56^{\mathrm{ab}}$ & $25.80 \pm 0.38^{\mathrm{a}}$ & $25.70 \pm 0.96^{\mathrm{a}}$ & $23.85 \pm 0.68^{b}$ & * \\
\hline TCL & $15.56 \pm 0.05$ & $14.00 \pm 0.09^{c}$ & $15.53 \pm 0.23^{b c}$ & $15.57 \pm 0.24^{b c}$ & $15.98 \pm 0.39^{b}$ & $16.70 \pm 0.22^{\mathrm{a}}$ & $* * *$ \\
\hline TTL & $1.61 \pm 0.02$ & $0.99 \pm 0.24^{\mathrm{c}}$ & $1.59 \pm 0.11^{\mathrm{ab}}$ & $1.70 \pm 0.18^{b c}$ & $1.82 \pm 0.10^{\mathrm{ab}}$ & $1.95 \pm 0.12^{\mathrm{ab}}$ & $*$ \\
\hline $\mathrm{UC}$ & $22.67 \pm 0.27$ & $17.30 \pm 0.50^{\mathrm{bc}}$ & $22.44 \pm 0.46^{\mathrm{b}}$ & $23.65 \pm 0.97^{\mathrm{a}}$ & $25.77 \pm 0.64^{\mathrm{a}}$ & $24.50 \pm 0.46^{\mathrm{ab}}$ & $* * *$ \\
\hline
\end{tabular}

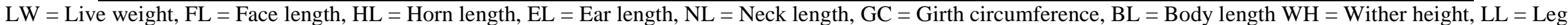

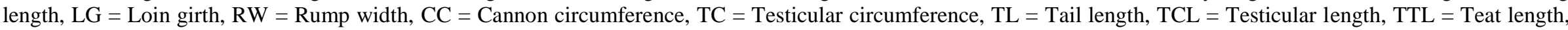

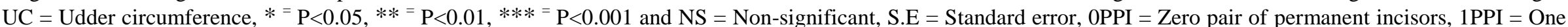

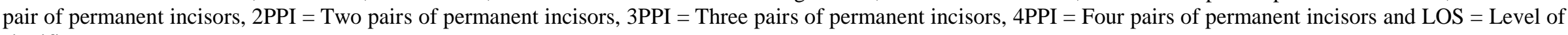
significance 
International Journal of Advances in Scientific Research and Engineering (ijasre), Vol 5 (2), February-2019

Table 6: Phenotypic correlation coefficients of body weight $(\mathrm{kg})$ and linear body Measurements $(\mathrm{cm})$ in male sheep

\begin{tabular}{|c|c|c|c|c|c|c|c|c|c|c|c|c|c|c|}
\hline Parameters & 2 & 3 & 4 & 5 & 6 & 7 & 8 & 9 & 10 & 11 & 12 & 13 & 14 & 15 \\
\hline LW (1) & $0.359^{* *}$ & $0.510^{* *}$ & $0.397^{* *}$ & $0.217^{* *}$ & $0.980^{* *}$ & $0.841^{* *}$ & $0.722^{* *}$ & $0.431^{* *}$ & $0.896^{* *}$ & $0.607^{\text {** }}$ & $0.498^{* *}$ & $0.320^{* *}$ & $0.466^{* *}$ & $0.337^{* *}$ \\
\hline FL (2) & & $0.234^{* *}$ & $0.187^{\mathrm{ns}}$ & $0.267^{* *}$ & $0.469^{* *}$ & $0.332^{* *}$ & $0.297^{* *}$ & $0.275^{* *}$ & $0.218^{* *}$ & $0.165^{\mathrm{ns}}$ & $0.117^{\mathrm{ns}}$ & $0.043^{\mathrm{ns}}$ & $0.044^{\mathrm{ns}}$ & $0.242^{* *}$ \\
\hline HL (3) & & & $0.304^{* *}$ & $0.447^{* *}$ & $0.532^{* *}$ & $0.611^{* *}$ & $0.483^{* *}$ & $0.274^{* *}$ & $0.431^{* *}$ & $0.049^{\mathrm{ns}}$ & $0.121^{\mathrm{ns}}$ & $0.297^{* *}$ & $0.186^{\mathrm{ns}}$ & $0.207^{* *}$ \\
\hline EL (4) & & & & $0.238^{* *}$ & $0.261^{* *}$ & $0.404^{* *}$ & $-0.049^{\mathrm{ns}}$ & $0.205^{* *}$ & $0.248^{* *}$ & $0.097^{\mathrm{ns}}$ & $0.223^{* *}$ & $0.159^{*}$ & $0.254^{* *}$ & $0.116^{\mathrm{ns}}$ \\
\hline NL (5) & & & & & $0.287^{* *}$ & $0.231^{* *}$ & $0.146^{\mathrm{ns}}$ & $0.216^{* *}$ & $0.301^{* *}$ & $0.126^{\mathrm{ns}}$ & $0.194^{\mathrm{ns}}$ & $0.222^{* *}$ & $0.098^{\mathrm{ns}}$ & $0.175^{\mathrm{ns}}$ \\
\hline $\mathrm{GC}(6)$ & & & & & & $0.831^{* *}$ & $0.692^{* *}$ & $0.619^{* *}$ & $0.746^{* *}$ & $0.522^{* *}$ & $0.233^{* *}$ & $0.295^{* *}$ & $0.272^{* *}$ & $0.162^{* *}$ \\
\hline $\mathrm{BL}(7)$ & & & & & & & $0.754^{* *}$ & $0.348^{* *}$ & $0.422^{* *}$ & $0.236^{* *}$ & $0.116^{\mathrm{ns}}$ & $0.209^{* *}$ & $0.163^{\mathrm{ns}}$ & $0.218^{* *}$ \\
\hline WH (8) & & & & & & & & $0.296^{* *}$ & $0.571^{* *}$ & $0.366^{* *}$ & $0.124^{* *}$ & $0.455^{* *}$ & $0.137^{\mathrm{ns}}$ & $0.262^{* *}$ \\
\hline LL (9) & & & & & & & & & $0.184^{*}$ & $-0.074^{\mathrm{ns}}$ & $0.192^{*}$ & $0.316^{* *}$ & $0.138^{\mathrm{ns}}$ & $0.197^{*}$ \\
\hline LG (10) & & & & & & & & & & $0.464^{* *}$ & $0.097^{\mathrm{ns}}$ & $0.141^{\mathrm{ns}}$ & $0.089^{\mathrm{ns}}$ & $0.212^{* *}$ \\
\hline RW (11) & & & & & & & & & & & $0.024^{\mathrm{ns}}$ & $0.118^{\mathrm{ns}}$ & $0.203^{* *}$ & $0.066^{\mathrm{ns}}$ \\
\hline $\mathrm{CC}(12)$ & & & & & & & & & & & & $0.161^{\mathrm{ns}}$ & $0.188^{\mathrm{ns}}$ & $0.045^{\mathrm{ns}}$ \\
\hline TL (13) & & & & & & & & & & & & & $0.0974^{\mathrm{ns}}$ & $0.163^{\mathrm{ns}}$ \\
\hline $\mathrm{TC}(14)$ & & & & & & & & & & & & & & $0.315^{* *}$ \\
\hline TCL (15) & & & & & & & & & & & & & & 1 \\
\hline
\end{tabular}


International Journal of Advances in Scientific Research and Engineering (ijasre), Vol 5 (2), February-2019

Table 7: Phenotypic correlation coefficients of body weight $(\mathrm{kg})$ and linear body Measurements $(\mathrm{cm})$ in female sheep

\begin{tabular}{|c|c|c|c|c|c|c|c|c|c|c|c|c|c|}
\hline Parameters & 2 & 3 & 4 & 5 & 6 & 7 & 8 & 9 & 10 & 11 & 12 & 13 & 14 \\
\hline LW (1) & $0.378^{* *}$ & $0.439^{* *}$ & $0.397^{* *}$ & $0.926^{* *}$ & $0.712^{* *}$ & $0.796^{* *}$ & $0.634^{* *}$ & $0.849^{* *}$ & $0.592^{* *}$ & $0.212^{* *}$ & $0.498^{* *}$ & $0.114^{\mathrm{ns}}$ & $0.247^{\text {** }}$ \\
\hline FL (2) & & $0.218^{* *}$ & $0.101^{\mathrm{ns}}$ & $0.331^{* *}$ & $0.249^{* *}$ & $0.131^{\mathrm{ns}}$ & $0.253^{* *}$ & $0.311^{* *}$ & $0.220^{* *}$ & $0.042^{\mathrm{ns}}$ & $0.104^{\mathrm{ns}}$ & $0.062^{\mathrm{ns}}$ & $0.281^{* *}$ \\
\hline EL (3) & & & $0.316^{* *}$ & $0.524^{* *}$ & $0.471^{* *}$ & $0.533^{* *}$ & $0.279^{* *}$ & $0.391^{* *}$ & $0.225^{* *}$ & $0.016^{\mathrm{ns}}$ & $0.395^{* *}$ & $0.101^{\mathrm{ns}}$ & $0.191^{*}$ \\
\hline NL (4) & & & & $0.179^{*}$ & $0.286^{* *}$ & $0.376^{* *}$ & $-0.071^{\mathrm{ns}}$ & $0.228^{* *}$ & $0.184^{* *}$ & $-0.047^{\mathrm{ns}}$ & 0.273 & $0.192^{*}$ & $-0.038^{n}$ \\
\hline $\mathrm{GC}(5)$ & & & & & $0.772^{* *}$ & $0.631^{* *}$ & $0.314^{* *}$ & $0.846^{* *}$ & $0.511^{* *}$ & $0.114^{*}$ & $0.539^{* *}$ & $0.227^{* *}$ & $0.243^{* *}$ \\
\hline BL (6) & & & & & & $0.751^{* *}$ & $0.264^{* *}$ & $0.596^{* *}$ & $0.488^{* *}$ & $-0.022^{\mathrm{ns}}$ & $0.374^{* *}$ & $0.117^{\mathrm{ns}}$ & $0.012^{\mathrm{ns}}$ \\
\hline WH (7) & & & & & & & $0.297^{* *}$ & $0.618^{* *}$ & $0.447^{* *}$ & $0.126^{\mathrm{ns}}$ & $0.466^{* *}$ & $0.129^{*}$ & $-0.011^{\mathrm{n}}$ \\
\hline LL (8) & & & & & & & & $0.296^{* *}$ & $0.187^{*}$ & $-0.046^{\mathrm{ns}}$ & $0.342^{* *}$ & $0.116^{\mathrm{ns}}$ & $0.192^{*}$ \\
\hline LG (9) & & & & & & & & & $0.528^{* *}$ & $0.314^{* *}$ & $0.397^{* *}$ & $0.241^{* *}$ & $0.212^{* *}$ \\
\hline RW (10) & & & & & & & & & & $-0.034^{\mathrm{ns}}$ & $0.246^{* *}$ & $0.118^{\mathrm{ns}}$ & $0.266^{* *}$ \\
\hline $\mathrm{CC}(11)$ & & & & & & & & & & & $0.195^{*}$ & $0.061^{\mathrm{ns}}$ & $0.011^{\mathrm{ns}}$ \\
\hline TL (12) & & & & & & & & & & & & $0.028^{\mathrm{ns}}$ & $0.175^{\mathrm{ns}}$ \\
\hline TTL (13) & & & & & & & & & & & & & $0.215^{* *}$ \\
\hline $\mathrm{UC}(14)$ & & & & & & & & & & & & & 1 \\
\hline
\end{tabular}

$\mathrm{BW}=$ Body weight, $\mathrm{FL}=$ Face length, $\mathrm{EL}=$ Ear length, $\mathrm{NL}=$ Neck length, $\mathrm{GC}=$ Girth circumference, $\mathrm{BL}=$ Body length, $\mathrm{WH}=\mathrm{Wither}$ height, $\mathrm{LL}=\mathrm{Leg}$ length, $\mathrm{LG}=$ Loin girth, $\mathrm{RW}=$ Rump width, $\mathrm{CC}=$ Cannon circumference, $\mathrm{TL}=$ Tail Length, $\mathrm{TTL}=$ Teat Length, $\mathrm{UC}=$ Udder circumference, $*=\mathrm{P}<0.05, * *=\mathrm{P}<0.01$ and $\mathrm{ns}=$ nonsignificant. 